\title{
Prateka Sawa Dengan Upacara Ngaben Kanista Pada Masa Pandemi Covid-19 di Kelurahan Abianbase Kecamatan Mengwi Kabupaten Badung
}

\author{
I Wayan Sujana \\ Universitas Hindu Negeri I Gusti Bagus Sugriwa Denpasar \\ iwayansujana70@gmail.com
}

\begin{abstract}
One element of the aspect ceremonial that has recently received attention in religious activities is the ceremony prateka sawa at the ceremony ngaben kanista during the covid-19 pandemic period in Abianbase Village, Mengwi District, Badung Regency. In the current situation, according to government regulations through the relevant health office, if a person dies from the corona virus, the body is immediately handled by Covid19 officers and taken to the crematorium. Because it is dangerous and can be contagious. Usually, public hospitals in Badung Regency are brought to the Santa Yana creatorium on Jalan Ahmad Yani Peguyangan or directly taken to the Bebalang Bangli Crematorium. The background of theritual prateka sawa during the covid-19 pandemic not only based on bhisama as the most important reason but also strengthened by socio-religious, cultural and economic reasons. This is accompanied by adaptations to strengthen the achievement of goals, strengthen integration and social control in the form of not daring to violate because of being cursed. Theritual system prateka sawa ritual for the diversity of Hindus in Abianbase Village continues with cremation related to the system religious, meaning that there are components such as beliefs, religious emotions, ritual systems, ritual equipment from religious people. These components synergize in a series of processes so as to give birth to the separation of the unification of the spirit into the sublime world with the mention of Dewa Hyang. The ritual of prateka sawa performed by the abianbase community has implications for variations on the abianbase community.
\end{abstract}

Keywords: Preteka Sawa; Ngaben; Covid-19

\begin{abstract}
Abstrak
Salah satu elemen dari aspek upacara yang belakangan ini mendapatkan perhatian dalam aktivitas keagamaan adalah upacara prateka sawa dengan upacara ngaben kanista pada masa pandemi covid-19 di kelurahan Abianbase, Kecamatan Mengwi, Kabupaten Badung. Dalam situasi sekarang ini sesuai aturan pemerintah melalui Dinas kesehatan terkait, apabila terdapat orang yang meninggal dikarenakan covid-19 maka mayatnya langsung di tangani oleh petugas covid-19 dan di bawa ke krematorium. Hal tersebut dikarenakan membahayakan dan dapat menular. Biasanya Rumah Sakit umum di Kabupaten Badung oleh pihak/ petugas mayatnya dibawa ke Kreatorium Santa Yana di Jalan Ahmad Yani, Peguyangan atau langsung dibawa ke Krematorium Bebalang Bangli. Latar belakang dilaksanakannya ritual prateka sawa dimasa pandemi covid-19 tidak saja berdasarkan dari pada bhisama sebagai alasan yang paling penting tetapi diperkuat pula oleh alasan sosial agama, budaya dan ekonomi. Hal ini disertai dengan adaptasi pemantapan pencapaian tujuan, penguatan integrasi dan kontrol sosial dalam bentuk tidak berani melanggar karena terkena kutukan. Sistem ritual prateka sawa terhadap keberagamaan umat Hindu di Kelurahan Abianbase berlanjut dengan ngaben. Terkait pada sistem religi, artinya ada komponen-komponen seperti keyakinan, emosi agama,
\end{abstract}


sistem ritual, peralatan ritual dari umat beragama. Komponen itu bersinergi dalam satu rangkaian proses sehingga melahirkan perpisahan penyatuan roh kedalam dunia luhur dengan penyebutan Dewa Hyang. Ritual prateka sawa yang dilakukan oleh masyarakat Abianbase menimbulkan implikasi variasi terhadap warga Abianbase.

Kata Kunci: Prateka Sawa; Ngaben; Covid-19

\section{Pendahuluan}

Upacara pitra yadnya bagi umat Hindu di Bali memiliki arti dan cara pelaksanaan tersendiri. Upacara keagamaan ini diadakan dengan maksud untuk ngaskara (mengupacarai sesuai ajaran agama) jenazah dan atma orang yang meninggal dengan berbagai upakara (sarana, sesajen) dan upacaranya, sesuai petunjuk yang diberikan oleh para Empu, seperti Empu Kuturan, Dang Hyang Dwijendra (Nirartha), Empu Klutuk dan lain-lainnya. Diselaraskan pula dengan tradisi (drsta), terutama menurut purwa drsta (warisan sejak dahulu), loka drsta (tradisi lokal/ daerah setempat), desa dresta (tradisi yang berlaku di suatu desa) dan kula drsta (kebiasaan serta kepercayaan keluarga bersangkutan). Adanya penyesuaian ini menyebabkan pelaksanaan upacara Pitra Yajnya, termasuk Prateka Sawa pada Upacara Ngaben Kanista pada masa pandemi covid-19, di berbagai tempat di Bali maupun di tempat lainnya tidaklah seragam, hanya inti serta tujuannya yang utama saja yang sama. Tubuh manusia menurut ajaran Hindu terdiri atas sthula atau raga sarira (badan kasar), suksma sarira (badan halus) dan anta karana sarira (atma/ jiwatman). Tubuh ini sebenarnya merupakan bagian kecil dari alam semesta. Oleh sebab itu tubuh manusia ini disebut bhuwana alit (mikrokosmos) dan jagat raya disebut bhuwana agung (makrokosmos). Keduanya memiliki bahan yang sama dalam perwujudannya. Oleh karena itu bila manusia meninggal, maka bahan dasar pembentuknya akan kembali ke alam ini, atau bhuwana alit akan manunggal dengan bhuwana agung. Raga (sarira) manusia yang terdiri atas kulit, daging, tulang, air, udara, api, rongga atau saluran sebagai wujud panca maha bhuta dari bhuwana alit akan kembali ke asalnya, yakni unsur panca maha bhuta yang ada di bhuwana agung atau alam ini.

Secara rinci unsur padat dari tubuh manusia yang berupa rambut, kulit, daging, tulang, ginjal, jantung, paru, hati, otak dan bagian lainnya dari tubuh yang berbentuk padat akan kembali ke unsur pertiwi pada panca maha bhuta. Plasma darah, cairan limpa, cairan pencernaan, cairan otak, air ludah dan bentuk cair lainnya yang ada di dalam tubuh manusia akan kembali ke unsur apah pada panca maha bhuta. Panas tubuh, api (enzim) pencernaan, kilatan mata, gigi, dan semua unsur panas serta yang memancarkan cahaya akan kembali ke unsur teja pada panca maha bhuta. Udara dalam paru-paru, udara dalam tulang, gas yang ada di dalam sel tubuh akan kembali ke unsur bayu pada panca maha bhuta (Rismayanti, 2017). Semua ruangan dalam tubuh manusia, rongga atau saluran yang terdapat pada pembuluh darah, saluran empedu, saluran limpa, saluran usus, saluran kencing, rongga peranakan, kandung kencing, rongga dada serta ruang yang terdapat di dalam tubuh manusia akan kembali ke unsur akasa pada panca maha bhuta (bhuwana agung). Jadi bagian tubuh manusia yang berupa zat padat kembali ke unsur prthiwi, zat cair kembali ke unsur apah, zat gas kembali ke unsur bayu, panas kembali ke unsur teja dan ruang kembali ke unsur akasa pada panca maha bhuta (bhuwana agung). Prateka Sawa pada Upacara Ngaben Kanista di masa pandemi Covid-19 di Kelurahan Abianbase Kecamatan Mengwi Kabupaten Badung adalah salah satu bagian dari upacara pitra yajnya yang pada intinya lebih banyak mengupacarai badan wadag tersebut dengan baik. Walaupun orang sudah dalam keadaan meninggal, diharapkan bila arwah yang bersangkutan berinkarnasi akan menjadi orang lebih sempurna (Darmayani et al., 2017). 
Prateka sawa dengan upacara ngaben kanista pada masa pandemi Covid-19 di kelurahan abianbase kecamatan mengwi pada dasarnya sangat kompleks dan rumit karena mengandung banyak nilai etika dan nilai filosofis yang bermakna tinggi. Oleh sebab itu urutan upacara prateka sawa dengan upacara ngaben kanista pada masa pandemi, penerapan protokol kesehatan covid-19 di kelurahan abianbase kecamatan mengwi diberlakukan secara ketat karena pada faktanya masyarakat yang melakukan upacara ini sering secara tidak sengaja melanggar etika dan urutan yang sebenarnya (protokol Kesehatan). Walaupun kelihatannya tidak memiliki masalah, tetapi bila dilihat dari makna dan tujuan upacara tersebut, serta jika salah melakukan maka upacara tersebut tidak akan memiliki makna (Gunada, 2017). Terkait dengan alat-alat upacara yang digunakan selalu disesuaikan dengan situasi, kondisi atau keadaan setempat. Bila alatalat (eteh-eteh) tersebut tidak memungkinkan tersedia, maka upacara prateka sawa dengan upacara ngaben kanista pada masa pandemi covid-19 di Kelurahan Abianbase Kecamatan Mengwi Kabupaten Badung tetap bisa dilaksanakan dengan mengedepankan etika dan tata cara yang sesuai dengan runtutannya. Disamping itu perbedaan penggunaan alat-alat di suatu tempat dengan tempat yang lain tidaklah menjadi masalah karena fungsi dan maknanya adalah sama.

Fenomena yang terjadi bahwa upacara prateka sawa dengan upacara ngaben kanista pada masa pandemi covid-19 di Kelurahan Abianbase menimbulkan pro dan kontra (pakrimik) pada masyarakat desa Adat di Kabupaten Badung, sebab ritual ini dianggap aneh ketika prosesi upacara Prateka Sawa pada upacara ngaben kanista dilaksanakan pada saat situasi pandemi covid-19 dengan suasana penerapan protokol kesehatan. Proses upacara ngaben kanista dilaksanakan di kuburan desa adat, sementara desa adat yang lain khususnya di Kabupaten Badung belum pernah ada yang melaksanakannya. Ketika ada masyarakat khususnya umat hindu yang meninggal akibat virus covid-19 melalui dinas kesehatan dan pihak rumah sakit kabupaten badung biasanya di bakar melalui krematoriun seperti krematorium Santa Yana di Peguyangan, krematorium Bebalang, Bangli dan itupun hanya dilaksanakan oleh petugas covid-19. Oleh karena itu hal tersebut merupakan permasalahan yang patut dijelaskan secara tuntas kepada umat Hindu agar tidak timbulnya salah tafsir.

Hal ini menarik untuk dikaji, tidak hanya untuk mencari masalah atau latar belakang situasi, namun juga untuk mencegah terjadinya konflik. Ritual apapun yang dilakukan oleh penganut suatu agama dapat dipandang suatu sistem religi. Sistem atau komponen yang lain adalah emosi keagamaan, umat agama, peralatan ritual, sistem ritual, yang kemudian membantu suatu sistem berproses untuk membentuk ritual. Sistem ritual berurutan dengan sisitem religi dan bersinergi terhadap dresta yang berlaku, berbicara masalah kematian yang sarat akan berbagai aturan seperti misalnya penentuan hari baik (subha dewasa), segi pelaksanaan upacara, masalah masa kecuntakaan maupun yang lainnya berlaku di setiap wilayah satu berbeda dengan wilayah lain, hal itu sesuai dengan kesepakatan yang telah ditetapkan. Demikian pula halnya dengan proses upacara ngaben kanista yang dilaksanakan di kelurahan Abianbase oleh suatu kelompok umat Hindu jauh berbeda dengan keluarga lainnya di luar kelurahan Abianbase.

\section{Metode}

Penelitian ini merupakan jenis penelitian dengan metode kualitatif. Penelitian ini dilakukan di Kelurahan Abianbase, Kecamatan Mengwi, Kabupaten Badung. Suatu kajian wilayah menempatkan desa ke dalam konteks yang lebih luas, menggambarkan fitur-fitur unik dan tipikal wilayah tersebut. Data komperatif juga membantu menjelaskan masalah-masalah yang ditemui dalam studi terhadap Desa. 
Lebih jauh studi seperti itu menunjukan hubungan-hubungan antar Desa dan jaringan regional yang merupakan elemen esensial masyarakat Bali. Sumber data primer adalah objek yang diobservasi langsung di lapangan dan informan yang diwawancarai (Sugiyono, 2018). Dengan kata lain data primer adalah data yang diperoleh langsung di lokasi penelitian, melalui proses wawancara dengan para informan. Adapun data sekunder berupa dokumentasi dan arsip-arsip resmi yang dapat mendukung hasil penelitian, sehingga dalam penelitian ini data primer didapat berdasarkan wawancara mendalam dengan para tokoh-tokoh masyarakat.

\section{Hasil Dan Pembahasan}

\section{Mempertahankan Adat dan Agama dalam Pelaksanaan Ritual Prateka Sawa dengan Upacara Ngaben Kanista pada Masa Covid-19}

Selain pengamalan ajaran agama, belum cukup hanya dengan melaksanakan tattwa dan etika saja tanpa dilengkapi dengan pengorbanan baik bersifat moral spritual maupun material. Suatu pengertian bahwa, manusia diciptakan oleh Ida Sang Hyang Widhi tidak hanya berupa atma dan roh saja namun lengkap diciptakan dengan materialnya berupa kekuatan prakertinya, serta bermanifestasi menjadi kekuatan Panca Maha Bhuta untuk membentuk adanya stula sarira (badan kasar), sehinga terlihat adanya keidupan di alam semesta ini. Oleh karena itulah umat Hindu menyampaikan rasa bhaktinya kehadapan Ida Sang Hyang Widhi yang bersifat Wahya Dyatmika (Sudarsana, 2002).

Terdapat beberapa hal dan prinsip yang harus dilakukan dalam pelaksanaan preteka sawa bagi seseorang yang baru meninggal yaitu jenasah diletakan pada balai dengan kepala menghadap kehulu yaitu kangin (timur) atau kaja. Sekujur tubuhnya di bungkus dengan menggunakan kain putih. Proses ini di laksanakan oleh pihak keluarga terdekat karena penentu proses berlangsungnya yajnasa terutama nyiramang layon atau pengringkes belum pasti (Kiriana, 2017). Adapun nilai etika yang terkandung ke dalam pelaksanaan suatu upacara adalah merupakan manisfestasi dari nilai tattwanya, sehinga umat Hindu bisa melakukan prilaku yang berbudi luhur, untuk mencapai subhakarma mereka tidak bisa mengucapkan mantra atau mengucapkan sloka-sloka dalam veda.

Penyampaian rasa bhaktinya yang bersifat wahya adalah berupa upakara dan penyampaiyan yang bersifat dyatmika adalah berupa pelaksana upacaranya (tattwa dan etikanya). Keduanya dilakukan secara bersamaan, dan itulah yang disebut pengalman ajaran agama secara utuh. Sistem etika mengacu pada sistem deontologikal yang berlaku secara absolut, mutlak dan harus diikuti dan sistem teologikal dengan pertimbangan yang baik dan buruk. Sistem ini merupakan segala tindakan yang mengacu pada sistem agama, logika hukum adat, logika hukum alam dan kondisi (desa, kala, patra) sehingga dihadapkan pada suatu kondisi yang sifatnya darurat harus ditentukan pada satu pilihan namun tidak boleh lepas dari prinsip moral (Agung, 2008). Contohnya terdapat pada pelaksanaan hari raya nyepi kewajiban agama Hindu harus melaksanakan catur brata penyepian yang terdiri dari amati gni, amati karya, amati lelungan, amati lelanguan. Namun pada saat terdapat jenazah yang harus di bawa ke rumah sakit, sehinga dalam kondisi seperti ini alternatif pilihan dilaksanakan dengan tetap mengacu pada prinsip moral.

Untuk dapat menghayati Desa Adat secara sempurna hendaknyalah kita lebih berhati-hati karena di samping sifatnya yang sangat komplek, juga merupakan suatu kesatuan yang bulat, di mana semua pengertian luluh lebur menjadi satu tanpa kehilangan essensinya. Agama adalah merupakan jiwa dari desa Adat, antara jiwa dengan badan, demikian pula halnya agama dengan desa Adat, dua hal yang hubungannya dijalin secara 
halus di mana agama menyerapi dan menghayati seluruh kehidupan desa adat (Agus, 2002). Dan kini desa adat menghadapi angin baru yaitu angin barat yang tergolong asing baginya kalau tubuh desa adat tidak kuat, maka akan mengalami penyakit demam dan mati. Atau sebaliknya jika tubuh desa adat kuat maka akan kebal dengan segala jenis angin dan dapat menyesuaikan dirinya sehingga menjadi tubuh yang sangat sempurna dan kebal terhadap segala macam penyakit. Semuanya ini terletak dan tergantung pada generasi muda saat ini. Pondasi kokoh generasi muda hindu sangat diperlukan. Apabila diiming-imingi kemilauan-kemilauan dolar yang bertaburan, kalau salah dan terlena membawa diri dapat menjadi seorang pelacur yang terhina. Pada generasi muda Hindu terletak amanat nenek moyang dan leluhur. Menciptakan iklim yang fovorable untuk masa depan Desa Adat yang berada di pulau Bali dengan menyadari dan mengenali struktur sosial serta landasan hidup serta way of life dari masyarakat Desa Adat setempat merupakan hal yang sangat penting untuk dilakukan.

\section{Sistem Ritual Prateka Sawa dengan Upacara Ngaben Kanista pada Masa Pandemi Covid-19}

Bagi umat Hindu upacara prateka sawa atau memandikan jenazah merupakan bagian dari upacara pitra yadnya. Secara harfiah, Pitra berarti leluhur (orang tua) dan yadnya bermakna pengorbanan suci yang tulus ikhlas. Sehingga upacara pitra yajna diartikan sebagai suatu pengorbanan yang dilandasi hati yang tulus ikhlas dan suci kepada leluhur terutama bapak dan ibu (Suastini, 2020). Salah satu bentuk pengorbanan suci diwujudkan dengan melakukan suatu upacara terhadap badan jenazah (sawa wedana) dan jiwatma (atma wedana) dari orang tuanya ketika menginggal dunia.

Upacara Pitra Yajna bagi umat Hindu di Bali memiliki arti dan cara pelaksanaan tersendiri. Upacara keagamaan ini diadakan dengan tujuan untuk ngaskara (mengupacara sesuai ajaran Agama) jenazah dan atma orang yang meninggal dengan berbagai upakara (sarana, sajen) dan upacaranya disesuai dengan petunjuk yang diberikan oleh para empu, seperti Empu Kuturan, Dang Hyang Dwijendra (Nirartha), Empu Lutuk dan lain-lainnya. Dan juga diselaraskan dengan tradisi (Drsta), terutama menurut purwa (warisan sejak dahulu), desa (tradisi yang berlaku di suatu daerah) serta loka drsta (tradisi lokal setempat) atau kebiasaan serta kepercayaan masyarakat setempat. Karena adanya penyesuaian ini maka pelaksanaan upacara Pitra Yadnya termasuk ke dalam upacara Prateka Sawa. Di berbagai tempat di Bali maupun di tempat lainnya tidaklah seragam. Hanya inti serta tujuannya yang utama saja yang sama.

Tubuh manusia menurut ajaran Hindu terdiri atas sthula atau Raga sarira (badan kasar), suksma sarira (badan halus) dan atma (jivatman). Tubuh ini sebenarnya merupakan bagian kecil dari alam semesta. Alam inilah yang merupakan asal dan tempatnya hidup manusia di dunia ini. Oleh sebab itu mbuh manusia ini disebut bhuvana alit (mikrokosmos) dan jagat raya disebut bhuvana Agung (makrokosmos) (Seriati, 2015). Keduanya memiliki bahan yang sama dalam perwujudannya. Oleh karena itu bila manusia itu meninggal, maka bahan dasar pembentuknya akan kembali ke alam ini bhuvana alit akan manunggal dengan bhuvana agung. Raga sarira manusia yang terdiri atas kulit, daging, tulang, air, udara, api, rongga atau saluran sebagai bagian Panca Maha Bhuta dari bhuvana alit akan kembali ke asalnya, yakni unsur Panca Maha Bhuta yang ada di Bhuvana Agung atau alam ini (Segara, 2020). Secara terinci unsur padat dari tubuh manusia yang berupa rambut, kulit, daging, tulang, ginjal, jantung, paru, hati, otak dan bagian lainnya dari tubuh yang berbentuk padat akan kembali ke unsur pertiwi dari Panca Maha Bhuta. Plasma darah, cairan limpa, cairan pencernaan, cairan otak, air ludah dan bentuk cair lainnya yang ada di dalam tubuh manusia akan kembali ke unsur apah dari 
Panca Maha Bhuta. Panas tubuh, api (enzim) pencernaan, kilatan mata, gigi, kulit dan semua unsur panas serta memancarkan cahaya akan kembali ke unsur teja dari Panca Maha Bhuta. Udara dalam paru, udara dalam tulang, gas yang ada di dalam sel tubuh akan kembali ke unsur vayu dari Panca Maha Bhuta (Mulyadi \& Adi, 2016). Dan terakhir, semua ruangan, rongga atau saluran yang terdapat pada pembuluh darah, saluran empedu, saluran limpa, saluran usus, saluran kencing, rongga peranakan, kandung kencing, rongga dada serta paru dan ruang yang terdapat di dalam tubuh manusia akan kembali ke unsur akasa dari Panca Maha Bhuta Bhuvana Agung. Jadi bagian tubuh manusia yang berupa zat padat kembali ke unsur prthivi, zat cair kembali ke unsur apah, zat gas kembali ke unsur vayu, panas kembali ke unsur teja dan ruang kembali ke unsur Panca Maha Bhuta bhuwana Agung.



Gambar 1. Salah Satu Bentuk Proses Upakara Terhadap Mayat Yang Terkena Covid-19 (Sumber : Sujana, 2021)

Upacara prateka sawa adalah salah satu bagian dari upacara Pitra Yajna yang pada intinya lebih banyak mengupacarai bagaimana tentang pemeliharaan badan wadag tersebut dengan baik. Walaupun seseorang sudah dalam keadaan menjadi mayat, sehingga diharapkan bila ia berreinkarnasi (numitis) akan menjadi orang yang lebih sempurna dari sebelumnya (Suprapto, 2019). Sebagai manusia yang memiliki tri pramana (bayu, sabda, idep), yang tahu akan etika, buddhi dan nalar, sudah selayaknyalah melakukan suatu upacara sebagai suatu ungkapan rasa terima kasih yang tulus dan suci dari lubuk hati umatNya yang paling dalam ketika mengembalikan semua badan bhuvana alit (jenazah) ini ke tempat asalnya di bhuvana agung. Badan ini telah amat berjasa, dipinjam dan dipergunakan sewaktu hidup di dunia, turut pula mengalami suka dan duka selama manumadi di marcapada ini (Suardana et al., 2020). Tatkala manusia meninggal dunia, maka sudah selayaknyalah raga sarira dan suksma sarira dihaturkan kembali kehadapan Sang Hyang Panca Maha Bhuta dan jivatma dikembalikan kepada Sang Hyang Paramatma, dengan disertai suatu upacara sebagai rasa ungkapan terima kasih yang tulus suci dari umat sebagai peminjam kepada pemiliknya.

\section{a. Persiapan dan Peralatan Ritual Prateka Sewa}

Upacara atiwa-tiwa dimulai sejak almarhum menghembuskan nafas terakhir sampai upacara penguburan atau pembakaran (mengkingsan di gni). Adapun prosesinya sebagai berikut: 
1) Saat orang baru meninggal; dibersihkan (dimandikan) di tempat tidurnya, badannya diusap dengan air cendana, semua pakaiannya diganti, selanjutnya dipindahkan ke bale semanggen (bale adat)

2) Setelah di bale semanggen, dibuatkan upakara daksina-penyeneng, beras catur warna yang dialasi dengan sebuah ceper, selanjutnya daksina tersebut dipakai sarana memanggil (ngulapin) sekaligus stana (tempat) roh almarhum dan daksina ditaruh disamping sawa.

3) Pada hari pengeringkesannya; sawa diturunkan dari bale semanggen dan diletakkan di pepaga, dengan beralaskan daun pisang (disesuaikan sastra dan kula dresta), yang telah ditulis dengan aksara Ang (diujung) dan aksara $A h$ (dipangkal). Setelah sawa di pepaga; pakaiannya dibuka dan bagian kemaluannya ditutup dengan kain hitam.

Pada suatu kegiatan di masyarakat Bali kentongan ( kulkul) memegang peranan yang sangat penting. Suaranya menandakan memulainya kegiatan yang baik kegiatan Adat maupun kegiatan-kegiatan yang lainya. Ketika salah satu warga masyarakat yang meninggal maka kepala lingkungan dalam suatu masyarakat membunyikan kentongan ( $k u l k u l)$ sebanyak 3 kali yang menadakan pada saat itulah krama adat sudah mulai cutaka (sebel) (Wawancara: Korma, 2021). Setelah dibunyika kentongan (kulkul) sebanyak tiga kali seluruh warga Adat mengetahui tentang berita duka tersebut kemudian dilanjutkan membunyikan kentongan atau melaksanakan gotong-royong. Masyarakat secara serempak datang ke balai banjar/rumah duka untuk mempersiapkan bahan-bahan yang akan dipakai untuk sarana upacara nyiramang layon seperti bambu untuk alat-alat pedusan dan lain sebagainya.

Berbeda dengan sistem bentuk upakara dan uapacara serta penanganannya bagi seseorang yang meninggal dikarenakan penyakit covid-19. Sesuai hasil tes (ravid test) dan yang bersangkutan di nyatakan positif dan meninggal dunia maka pihak rumah sakit (dokter) berkoordinasi dengan pihak keluarga terkait proses penanganan mayat tersebut. Dari pihak keluarga diberikan kesempatan berkoordinasi dengan masyarakat untuk selanjutnya akan dilakukan proses krematorium (Rahmi Putri, 2017). Tidak terlepas juga dilakukan sembah kehadapan leluhur (kawitan) sekaligus dilakukan di luar areal kuburan oleh pihak keluarga lampus dengan penghormatan kepada roh sang lampus yang dipimpin langsung oleh pemangku. Dalam prosesi selanjutnya upacara dilaksanakan sangat sederhana mengingat surat edaran yang pada intinya upacara menurut Hindu tetap dilaksanakan seperti yang akan dipaparkan berikut ini sekaligus yang meninggal akibat covid-19 dan yang tidak terindeksi covid-19 sebagai berikut:

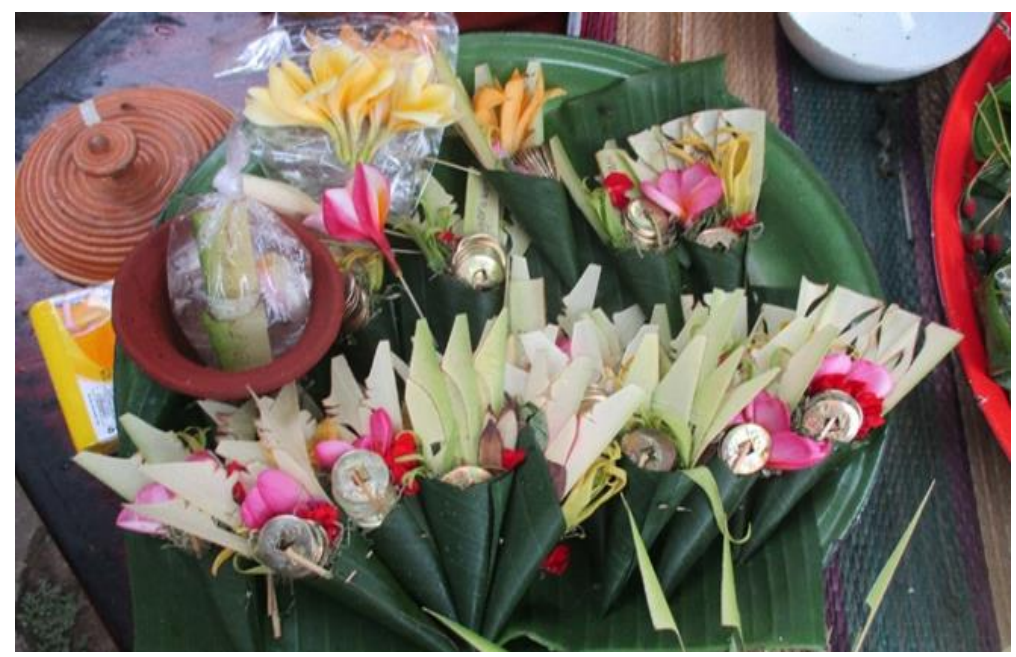

Gambar 2. Bentuk Kwangen Sebagai Perlengkapan Upacara Nyiramang Layon (Sumber : Sujana, 2021) 
1) Uparengga atau peralatan yang meninggal karena bukan terkena virus cororna (covid19) yaitu : sebuah papaga yang lengkap (sesuai desa dresta), sebuah ante dari bilahbilah bambu (tidak mutlak memakai ante), sebuah pelepah daun pisang (sesuai kula dresta), sebuah pisau sudha mala, sebuah peti sawa (tidak mutlak), tiga buah kerebsinom (rurubsinom), seutas tali rotan, selembar tikar. Uparengga atau peralatan yang meninggal akibat covid-19 yaitu; upakara seperi daksina dan tirtha hanya dialasi meja yang penempatannya di kuburan menunggu mayat dari rumah sakit.

2) Sarana pembersihan: air bersih biasa (air tawar) dan air kumkuman, air keramas, sigsig dan minyak wangi, bunga-bunga yang harum, pakaian saperadeg (satu stel busana adat) atau secukupnya, pembungkus/ penggulung bempa kain putih, samsam beras kuning. Tirta-tirta seperti: tirta pengelukatan dan pebersihan, tirta pengeringkesan, tirta pamerasan, tirta Bhatara Hyang Guru, banten: papegat dan banten pamerasan.

3) Sarana kelengkapan lainnya: gegaleng (pisang kayu) dan kewangen pangerekan penutup (penangkep) prerai (wajah) dan sarira (kemaluan) kain putih untuk tetindih yakni kain yang dipasang/ diikatkan di ujung tiap pepaga di atas sawa.

Disini diuraikan juga upacara atiwa-tiwa dengan upakara pada tingkatan inti (kanista) juga dipersiapkan sekaligus dengan peralatan upakaranya sebagai berikut: a). Upakara dihaturkan di Sang Hyang Widi Wasa Kemulan; (1) peras, soda, daksina, suci alita soroh, (2) Ketipat kelanan, canang pesucian. b). upakara yang dihaturkan di Sang Hyang Widi Wasa Surya (di pekarangan rumah), (1) peras, soda, daksina, (2) ketipat kelanan, canang pesucian, (3) toya anyar.

4) Upakara disamping sawa; a) peras soda daksina, b) ketipat kelanan, c) banten saji putih kuning, d) sayut pengambeyan, peras arepan, penyeneng, rantasan, e) eteh-eteh pesucian, beakaonan, pengulapan, prayascita, f) banten isuh-isuh, lis.

5) Upakara papegalan dan pamerasan; a) Pejati asoroh dihaturkan di Sang Hyang Widi Wasa Surya, banten penyambutan papegatan angiyu, a) sebuah, lesung dan segehan sasah 9 tanding, b) banten pamerasan asoroh. Upakara tersebut diatas diatur penempatannya oleh pihak pemangku dan petugas rumah sakit, keluarga hanya menyaksikan dari luar areal kuburan.

6) Jenis perlengkapan upacara/upakara yang terdapat di atas, khusus untuk mayat yang meninggal akibat covid-19 tetap menggunakan upakara tersebut hanya saja diletakan diatas meja disamping mayat dan pihak petugas didampingi pemangku yang lengkap memakai pakaian sesuai protokol kesehatan. Sehingga tidak ada alasan yang meninggal sampai tidak diupacarai. (Alit Bawa, wawancara tanggal 30 maret 2021).

\section{b. Pengangkatan Sawa dari Rumah Sakit Menuju Kuburan}

Upacara prateka sawa kelihatannya memang sangat sederhana, namun pada dasarnya upacara tersebut sangat kompleks dan rumit karena mengandung banyak nilainilai etika dan nilai filosofis yang bermakna tinggi. Oleh sebab itulah urutan-urutan tentang Upacara prateka sawa perlu diketahui secara baik karena pada dasarnya masyarakat yang melakukan penyiraman layon sering secara tidak sengaja melanggar etika dan urutan-urutan yang sebenarnya. Walaupun kelihatannya tidak memiliki masalah tetapi, bila dilihat dari makna dan tujuan upacara tersebut apabila salah rnelakukan maka upacara tersebut tidak akan memiliki makna. Mengenai alat-alat upacara yang digunakan tidak mutlak harus ada, hal itu harus disesuaikan dengan situasi, kondisi dan keadaan setempat (Darmayani et al., 2017). Bila alat-alat (eteh-eteh) tersebut tidak memungkinkan tersedia, maka upacara prateka sawa tetap bisa dilaksanakan dengan tetap mengedepankan etika dan tata cara yang sesuai dengan runtutannya. Selain itu perbedaan penggunaan alat-alat disuatu tempat dengan tempat yang lain tidaklah menjadi masalah karena fungsi dan maknanya adalah sama. 
Sebelum berangkat ke setra dimana akan tempat turunnya sawa untuk berangkat ke setra, disiapkan satu soroh banten yang disebut "Banten Turun Sawa", yang akan dilalui oleh mereka yang menggotong sawa untuk dinaikkan ke bade. Banten Turun Sawa yaitu; 1 soroh suci, 1 soroh sorohan, 1 soroh glarsanga, 1 soroh jejeg urip, 1 soroh sayut pengambiyan, 1 soroh caru ayam brumbun, 1 soroh lis amuan-amuan.

Banten tersebut kemudian ditutup dengan kain putih setelah sawa terangkat dari balai tempat sawa, maka balai diberi banten (tilur sawa) yaitu : satu soroh suci, satu soroh pejati, (dimuncuk daun abu aon tutup guwunga). Banten turun sawa cukup di rumah saja. Di jabe depan bade akan berangkat ke setra letakkan diatas meja sawa soroh "Banten Pepegatan" untuk simbol sebagai pemutusan hubungan, tidak teringat terus karena bisa terus terlarut dalam kesedihan. Setelah acara pepegat selesai barulah bade dan seluruh peserta berangkat ke setra dengan perjalanan setertibnya sesuai adat istiadat seternpat.

Berbeda dengan sesorang yang meninggal akibat terkena virus covid-19 maka mayatnya akan di tangani oleh pihak rumah sakit dengan pengawalan yang sangat ketat dengan protokol kesehatan. Dari pihak keluarga duka dikordinasikan dengan menyiapkan 1 (satu ) buah pejati, 1 (satu) kwangen dan mayat langsung di berangkatkan ke kuburan (krematorium). Setelah sampai di krematorium dari pihak rumah sakit memberikan kesempatan untuk berdoa dari kejauhan/dengan tempat yang sudah ditentukan oleh petugas, dengan tujuan supaya arwah atau atmanya berjalan dengan tenang serta mendapatkan tempat yang sangat baik.

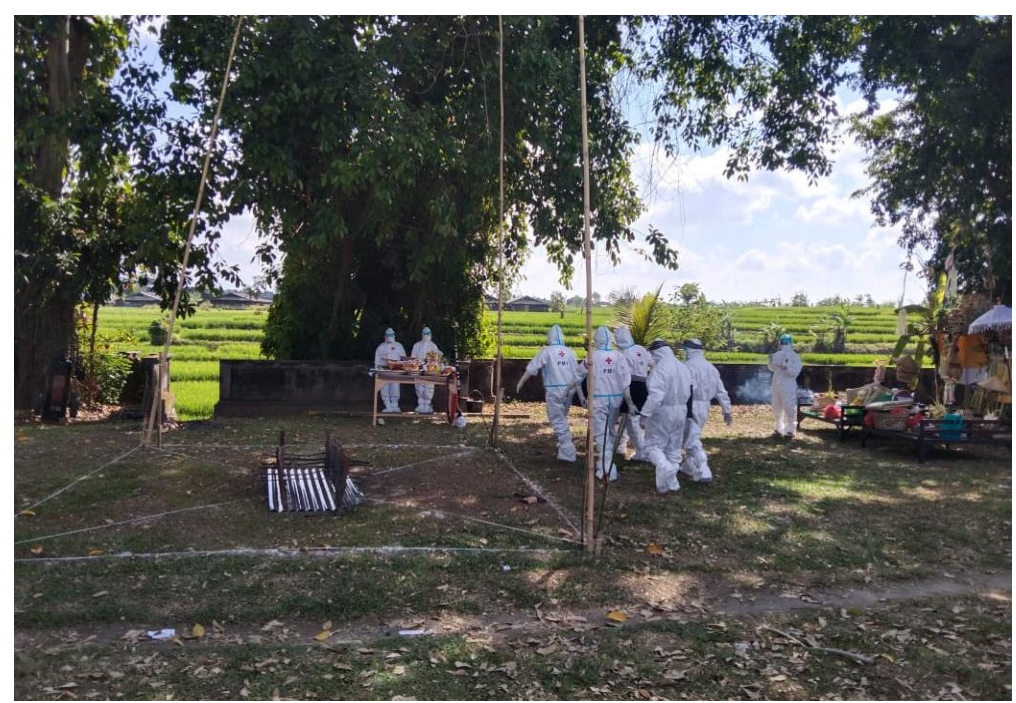

Gambar 3. Prosesi Upacara Prateka Sawa Setelah Tiba Di Kuburan

(Sumber: Sujana, 2021)

Berdasarkan gambar diatas dapat diuraikan bahwa setelah mayat sampai dikuburan maka petugas langsung mengusung mayat yang terkena covid-19 dari mobil menuju kuburan/setra dengan mengelilingi pemuhunan setra (tempat pembakaran mayat) sebanyak tiga kali dengan lengkap upakaranya yang dilaksanakan langsung oleh petugas rumah sakit. Setelah selesai mengelilingi kuburan tersebut maka sama seperti biasa mayat di taruh diatas kuburan tempat dimana mayat akan dibakar. Sebelum proses pembakaran prosesi seperti ngringkes, metirta yang sudah disiapkan oleh pihak keluarga tetap dilaksanakan hanya saja mayat tetap berada di dalam peti dan peti tertutup rapat. Prosesi membersihakan mayat hanya dilaksanakan dari luar saja oleh pihak petugas. Pihak keluarga dan masyarakat hanya bisa menyaksikan prosesi itu dari luar pagar mengingat pengamanan yang sangat ketat. 


\section{Kesimpulan}

Latar belakang ritual prateka sawa dengan upacara ngaben kanista pada masa pandemi covid-19 yang dilakukan di Kelurahan Abianbase, Mengwi, Badung ini disebabkan oleh berbagai faktor yakni; legitimasi berdasarkan situasi sehingga kuat keinginan melaksanakan dan menunjukan identitas dalam masyarakat yang berbeda dari pada yang lainnya. Begitu pula melalui ritual tersebut roh leluhur dan dewa-dewa yang bersemayam di sanggah atau Merajan Kamulan sebagai saksi ritual upacara Prateka sawa pada upacara ngaben kanista. Upacara ini terkait juga dengan ajaran agama Hindu pitra rnam. Mengingat upacara ini melibatkan warga dengan jumlah yang sangat terbatas di masyarakat maka ritual ini berfungsi untuk memperkuat solidaritas warga khususnya di Kelurahan Abianbase. Ritual ini dilaksanakan tidak juga dilepaskan dari adat istiadat lokal yang dikaitkan dengan agama Hindu. Sistem ritual prateka sawa yang berlaku dan mengikuti tata aturan tertentu mulai dari kesiapan menyambut kematian. Persiapan peralatan ritual dan penyelengaraan upacara. Adapun puncak upacara melibatkan kegiatan seperti pengangkut sawa dari rumah sakit langsung menuju kuburan (setra). Hal ini dilanjutkan dengan pekutangan yang di dalamnya menyangkut; mengusung mayat ke kuburan, membakar, ngreka tulang. Ritual selanjutnya ngrorasin dan ngelinggihang Dewa Hyang. Kesemua rangkaian ritual tersebut tidak bisa terlepas dari pemilihan dewasa ayu, penggunaan banten dan uparengga, keterlibatan pemimpin upacara, penyelenggara ritual dan masyarakat desa adat atau banjar adat yang ikut sebagai penyelenggara ritual upacara nyiramang layon. Ritual prateka sawa pada masa pandemi covid-19 yang dilakukan oleh krama atau warga kelurahan Abianbase menimbulkan implikasi variasi tradisi keagamaan antara warga desa adat dengan umat lain khususnya yang berada di Kelurahan Abianbase. Secara umum variasi ini muncul karena pemberian makna yang berbeda serta permasalah virus covid-19. Sebaliknya warga desa adat Abianbase memaknainya sendiri pada tradisi keagamaan yang umum berlaku pada masyarakat Bali. Perbedaan pemaknaan itulah yang pada mulanya menimbulkan konflik dengan warga masyarakat desa adat Abianbase secara keseluruhan. Walaupun terdapat pemaknaan esensi ritual prateka sawa dan memiliki implikasi yang sama dengan tradisi yang umum berlaku pada masyarakat Bali yakni; memperkuat sraddha bhakti, solidaritas antara warga dadia dan memperkuat solidaritas antar warga masyarakat bahkan ada juga implikasi lainnya adalah kematian sebagai keniscayaan bagi hidup manusia.

\section{Daftar Pustaka}

Agung, G. P. (2008). Cudamani Upacara Mapades dan Upacara Atiwa-tiwa (ngaben). Surabaya: Paramitha.

Agus, S. (2002). Estetika (Makna, Simbol dan Daya). Bandung: ITB.

Darmayani, L. L., Julianto, I. P., \& Atmadja, A. W. T. (2017). Fidusia Sebagai Jaminan dalam Pemberian Kredit Cepat Untuk Upacara Ngaben Di LPD Sumberkima. Ejournal - S1 Ak Universitas Pendidikan Ganesha, 8(2).

Gunada, I. W. A. (2017). Patulangan Bawi Srenggi Dalam Prosesi Ngaben Warga Tutuan Di Desa Gunaksa, Kabupaten Klungkung (Kajian Estetika Hindu). Jurnal Penelitian Agama Hindu.

Kiriana, I. N. (2017). Ngaben Conception In Lontar Siwa Tattwa Purana. Vidyottama Sanatana: International Journal of Hindu Science and Religious Studies, 1(2), 84.

Mulyadi, M., \& Adi, I. N. R. (2016). Partisipasi Dan Motivasi Masyarakat Dalam Pelaksanaan Upacara Ngaben Ngerit Serta Dampaknya Pada Kehidupan Masyarakat. Prosiding Seminar Nasional Hasil Penelitian-Denpasar, September 2016. 
Rahmi Putri, N. M. (2017). Komunikasi Simbolik Dalam Upacara Ngaben Matuun Di Desa Adat Munduk Lumbang Desa Angseri Kecamatan Baturiti Kabupaten Tabanan. Jurnal Penelitian Agama Hindu, 1(2).

Rismayanti Sari Dewi, P. W. (2017). Persepsi Umat Hindu Terhadap Keberdaan Krematorium Santayana Denpasar Bali. Jurnal Penelitian Agama Hindu, 1(2). https://doi.org/10.25078/jpah.v1i2.234

Segara, I. N. Y. (2020). "Bade Beroda": Transformasi dan Komodifikasi Budaya dalam Upacara Ngaben di Bali. Mudra Jurnal Seni Budaya, 35(1).

Seriati, N. N. (2015). Fungsi Tari Baris Dada Dalam Upacara Ngaben Di Banjar Bebali Tabanan Bali. Imaji, 2(2).

Suardana, I. W., Wairocana, I. G. N., \& Dharma Jaya, I. bagus S. (2020). Keabsahan Penerapan Pasal 93 Undang-Undang Kekarantinaan Kesehatan Di Wilayah Yang Tidak Menetapkan Pembatasan Sosial Berskala Besar. Kertha Semaya: Journal Ilmu Hukum, 8(9)

Suastini, N. W. (2020). Reinterpretation Of Mass Ngaben In Bali. E-Journal of Cultural Studies. https://doi.org/10.24843/cs.2020.v13.i04.p05

Sudarsana, I.B. (2002). Ajaran Agama Hindu (Upacara Pitra Yajna). Denpasar: Mandara Sastra.

Sugiyono. (2013). Metode Penelitian Pendidikan: Pendekatan Kuantitatif, Kualitatif, Dan R\&D. Bandung: Alfabeta.

Sugiyono. (2018). Metode Penelitian Kuantitatif,Kualitatif dan R\&D. In Ke-26. Bandung: Alfabeta.

Suprapto, P. (2019). Pemberdayaan sekehe patus ngaben sarwa guna yadnya di dusun silakarang, gianyar. Dharmakarya, 8(1). 